\title{
Botryosphaeriaceae associated with Acacia heterophylla (La Réunion) and Acacia koa (Hawaii)
}

\author{
Fahimeh Jami a, *, Seonju Marincowitz a, Bernard Slippers a, Pedro W. Crous ${ }^{\text {a, b }}$, \\ Johannes J. Le Roux ${ }^{c, d}$, David M. Richardson ${ }^{c}$, Michael J. Wingfield ${ }^{\text {a }}$ \\ a Department of Biochemistry, Genetics \& Microbiology, Forestry \& Agricultural Biotechnology Institute (FABI), University of Pretoria, Pretoria, South Africa \\ ${ }^{\mathrm{b}}$ Westerdijk Fungal Biodiversity Institute, Uppsalalaan 8, 3584 CT Utrecht, the Netherlands \\ ' Centre for Invasion Biology, Department of Botany \& Zoology, Stellenbosch University, Stellenbosch, South Africa \\ ${ }^{\mathrm{d}}$ Department of Biological Sciences, Macquarie University, Sydney, Australia
}

\section{A R T I C L E I N F O}

\section{Article history:}

Received 10 July 2018

Received in revised form

28 June 2019

Accepted 16 July 2019

Available online $\mathrm{xxx}$

Corresponding Editor: Nik Money

\section{Keywords:}

Biodiversity

Dothiorella

Multigene phylogeny

Taxonomy

\begin{abstract}
A B S T R A C T
Acacia koa and A. heterophylla are commonly occurring native trees on the Hawaiian Islands and La Réunion, respectively. A recent phylogenetic study suggested that $A$. heterophylla renders $A$. koa paraphyletic, and that the former likely arose from the Hawaiian Islands around 1.4 million years ago. An intriguing question is whether their microbiota is similar, although they occur naturally in two very distant geographical locations. In this study, we compared the fungi in the Botryosphaeriaceae isolated from natural populations of $A$. koa and $A$. heterophylla. These fungi were chosen because they commonly occur on woody plants and some are important pathogens. They are also known to have been moved globally on asymptomatic plant materials. Isolates were identified based on comparisons of DNA sequence data for the rDNA-ITS, TEF1- $\alpha$ and $\beta$-tubulin loci. Ten Botryosphaeriaceae species were identified, of which four species were specific to $A$. koa from the Hawaiian Islands and five to A. heterophylla in La Réunion. Only one species, Neofusicoccum parvum, which is known to have a wide global distribution, was common to both hosts. The overall results of this study suggest that although A. koa and A. heterophylla share a recent evolutionary history, they have established independent microbiota, at least in terms of the Botryosphaeriaceae.
\end{abstract}

๑) 2019 British Mycological Society. Published by Elsevier Ltd. All rights reserved.

\section{Introduction}

The Botryosphaeriaceae Theiss. \& Syd. (Botryosphaeriales, Dothideomycetes) includes 24 genera and over 100 species (Slippers et al., 2017; Yang et al., 2017) and is one of the most cosmopolitan groups of fungi occurring on woody plants. The Botryosphaeriaceae are typically endophytes that have evolved in close association with their hosts on which they can cause disease, usually under conditions of stress (Slippers and Wingfield, 2007; Mehl et al., 2013; Marsberg et al., 2017). Host stress factors are key issues in emerging diseases caused by Botryosphaeriaceae (Slippers and Wingfield, 2007) and climate change is increasing the risk of diseases caused by this group of fungi (Desprez-Loustau et al., 2006; Sturrock et al., 2011).

\footnotetext{
* Corresponding author.

E-mail address: fahimeh.jami@fabi.up.ac.za (F. Jami).
}

It is not clear if there are general patterns of host specificity in the Botryosphaeriaceae. While they are usually known to have wide host ranges and geographical distributions, some species have been found to display strong host specificity and limited geographic distributions (Slippers et al., 2017). These fungi are also known to have been moved extensively by humans due to global trade in plant material (Crous et al., 2016a; Burgess and Wingfield, 2017; Sakalidis et al., 2011a). Thus, even where the Botryosphaeriaceae have been isolated from native plants, they are not necessarily native to those plants. For example, Mehl et al. (2017) showed movement of these fungi between planted mango (Mangifera indica L.) trees and native marula trees (Sclerocarya birrea (A.Rich.)) Hochst. subsp. caffra (Sond.).

Acacia heterophylla Willd. and Acacia koa A. Gray are indigenous to La Réunion and Hawaiian Islands, respectively (Brown et al., 2012). These trees are particularly interesting because $A$. heterophylla is phylogenetically most closely related to A. koa (Le Roux et al., 2014), but they occur in areas very distant to each other in the Hawaiian Islands and La Réunion. Their unusual close relatedness relative to 
their areas of origin led Le Roux et al. (2014) to suggest that they represent a single taxon that have been separated for $c a$. 1.4 million years. Their hypothesis was that $A$. heterophylla was most likely introduced to La Réunion from Hawaiian Islands via a rare extreme long-distance dispersal event (Van Zandt et al., 2014).

There have been few studies conducted on the fungal community of $A$. heterophylla and $A$. koa trees based on molecular data. Only two fungi, Colletotrichum karstii You L. Yang et al. (HernandezRestrepo et al., 2016), and Vermiculariopsiella acaciae Crous \& M.J. Wingf. have been reported on leaves of A. heterophylla in La Réunion (Crous et al., 2016b). While there are more fungal reports from leaves of $A$. koa in Hawaii, such as Beltraniella acacia Crous, Dactylaria acacia Crous, Rhexodenticula acaciae Crous, Rubikia evansii Crous, Torula acaciae Crous (Crous et al., 2017), Calonectria ilicicola Boedijn \& Reitsma (Crous et al., 2004), and rust fungi such as Endoraecium acaciaei Hodges \& D.E. Gardner, E. hawaiiense Hodges \& D.E. Gardner and E. koae (Arthur) Scholler and Aime, (2006), there has never been a study on endophytic fungi of these trees in the areas where they occur naturally.

The aim of this study was to identify and compare the Botryosphaeriaceae species diversity on A. heterophylla and A. koa, and more broadly, to consider whether these fungi reflect the historical biogeography of these trees as documented by Le Roux et al. (2014).

\section{Materials and methods}

\subsection{Collection of samples and isolations}

Branch samples were collected from asymptomatic A. heterophylla on La Réunion Island during 2014 and from A. koa in the Hawaiian Islands during 2015. Five branches from each of 20 A. heterophylla and $25 \mathrm{~A}$. koa trees were randomly chosen for sampling. The collected branches ( $A$. heterophylla $=100$ and $A . k o a=125$ ) were placed in paper bags and transferred to the laboratory for further study. After storage at $4{ }^{\circ} \mathrm{C}$ for one week, 12 pieces $(0.5 \mathrm{~cm})$ were randomly selected from each branch, surface-disinfested in $10 \%$ hydrogen peroxide for two minutes, and rinsed three times in sterile water. All branch samples were placed on $2 \%$ malt extract agar (MEA) (Biolab, Midrand, South Africa) in Petri dishes with four samples per plate. Petri dishes were incubated at $24^{\circ} \mathrm{C}$ for seven days and fungal growth from each sample showing morphological characteristics (fast growing, white to black cultures with fluffy aerial hyphae) of the Botryosphaeriaceae were transferred to fresh MEA plates. After 4-5 d, all isolates showing typical growth were transferred to $15 \%$ water agar (WA) in order to make single hyphal tip subcultures. These isolates are maintained in the Culture Collection (CMW) of the Forestry and Agricultural Biotechnology Institute (FABI), University of Pretoria, Pretoria, South Africa. A sub-set of live cultures and dried cultures representing novel taxa were lodged at the South African National Collection of Fungi at Agricultural Research Centre, Plant Protection Research Institute (ARC-PPRI), Roodeplaat, South Africa.

\subsection{DNA sequence analyses}

DNA was extracted using a PrepMan ${ }^{\circledR}$ Ultra kit (Applied Biosystems) from mycelia taken from 5-d-old pure cultures. DNA sequences were generated for the internal transcribed spacer region of the ribosomal RNA (rRNA) operon amplified with primers ITS-1F (Gardes and Bruns, 1993) and ITS-4 (White et al., 1990), the translation elongation factor $1-\alpha(T E F 1-\alpha)$ gene amplified with primers EF1-728F and EF1-986R (Carbone and Kohn, 1999), as well as the $\beta$-tubulin (TUB2) gene amplified with primers BT2a and BT2b (Glass and Donaldson, 1995). The conditions for the PCR and DNA sequencing were the same as those described by Jami et al. (2012).

Phylogenetic analyses for all the datasets were performed using Maximum Likelihood (ML). The best-fit nucleotide substitution models for each dataset were identified separately using Modeltest v.3.7 (Posada and Buckley, 2004). The GTR model was identified for all datasets of ITS, TEF- $1 \alpha$ and TUB2 as well as the combined datasets. The ML analyses were performed in PAUP v.4.0b10 and confidence levels were determined with 1000 bootstrap replications. All the sequences of this study were deposited in GenBank (Table 1).

\subsection{Morphological characteristics}

To induce sporulation, cultures were inoculated onto sterilized twigs of Salix sp, placed on the surface of $2 \%$ MEA and incubated at $25{ }^{\circ} \mathrm{C}$ under near-UV light. Conidiomata harvested from hardwood twigs were dissected using a Cryomicrotome (Leica, Germany). Fungal structures were mounted in Tissue Freezing Medium ${ }^{\circledR}$ (Leica, Germany) and cut in 12-14 $\mu \mathrm{m}$ thickness. Sections were mounted in $85 \%$ lactic acid for observation. All measurements and images were taken using a Nikon Eclipse Ni compound and SMZ18 dissecting microscopes (Nikon, Japan). Images were captured with a Nikon DS-Ri camera and with the imaging software NIS-Elements BR. Up to 50 measurements were made for spores and other morphologically characteristic structures where these were available.

Growth in culture was studied in the dark at temperatures between $10^{\circ} \mathrm{C}$ and $35^{\circ} \mathrm{C}$ at $5^{\circ} \mathrm{C}$ intervals. An agar disc taken from the edge of an actively growing culture was placed at the centre of $90 \mathrm{~mm}$ Petri dishes containing $2 \%$ MEA. Three replicate plates were used for each isolate per temperature. Cultures were allowed to grow until the fastest growing isolate reached the edge of a Petri dish at which point the experiment was terminated and two measurements perpendicular to each other of colony diameters were made. The averages of the colony diameters were then calculated. Colony colours were assigned using the designations of Rayner (1970).

\section{Results}

\subsection{Isolates and DNA sequence analyses}

A total of 16 isolates were obtained from seven asymptomatic A. koa (25 sampled trees) and eight isolates from seven asymptomatic $A$. heterophylla (20 sampled trees) (Table 1 ). The sequence datasets for the ITS, TUB2 and TEF- $1 \alpha$ were analysed individually and in combination (Figs. 1, S1-S3). The ITS sequence dataset contained 579 characters, TUB2 dataset contained 412 characters, $T E F-1 \alpha$ dataset contained 409 characters and combined dataset contained consisted of 1400 characters (TreeBASE Accession No. 22704).

The topologies of the trees emerging from the ML analyses were similar for the individual gene regions (Figs. S1-S3), as well as in the combined analyses, with regards to the clades representing species isolated in this study. Ten clades were identified in all the analyses, representing (Neofusicoccum occulatum Sakalidis \& T.I. Burgess, Neofusicoccum parvum Pennycook \& Samuels) Crous et al., Lasiodiplodia theobromae (Pat.) Griffon \& Maubl., Lasiodiplodia exigua Linald. et al., (=Lasiodiplodia americana S.F. Chen et al.), Lasiodiplodia iraniensis Abdollahz. et al., (=Lasiodiplodia jatrophicola A.R. Machado \& O.L. Pereira), Lasiodiplodia rubropurpurea T.I. Burgess et al., Botryosphaeria ramosum (Pavlic et al.) A.J.L. Phillips \& A. Alves and three unknown groups in the genus Dothiorella Sacc. (Fig. 1). Five species were specific to samples from $A$. koa in the Hawaiian 
Table 1

The Botryosphaeriaceae isolates from Acacia heterophylla and A. koa of this study used in the phylogenetic analyses. Type isolates are indicated in bold.

\begin{tabular}{|c|c|c|c|c|c|c|}
\hline \multirow[t]{2}{*}{ Isolate No. } & \multirow[t]{2}{*}{ Identity } & \multirow[t]{2}{*}{ Location } & \multirow[t]{2}{*}{ Host } & \multicolumn{3}{|l|}{ GenBank } \\
\hline & & & & ITS & $T E F 1-\alpha$ & TUB2 \\
\hline CMW 46460 & Botryosphaeria ramosaum & La Réunion & Acacia heterophylla (tree no. 2) & MH447651 & - & MH548326 \\
\hline CMW 46457 ${ }^{\mathrm{T}}$ & Dothiorella reunionis sp. nov. & La Réunion & A. heterophylla (tree no. 3 ) & MH447649 & MH548347 & - \\
\hline CMW $46458^{T}$ & Dothiorella heterophyllae sp. nov. & La Réunion & A. heterophylla (tree no. 5) & MN103794 & MH548348 & MH548324 \\
\hline CMW 48017 & Dothiorella koae sp. nov. & Hawaii & A. koa (tree no. 12 ) & MH447652 & MH548338 & MH548327 \\
\hline CMW 48018 & & Hawaii & A. koa (tree no. 1) & MH447653 & MH548337 & MH548328 \\
\hline CMW 48019 & & Hawaii & A. koa (tree no. 1$)$ & MH447654 & MH548336 & MH548329 \\
\hline CMW 48020 & & Hawaii & A. koa (tree no. 1$)$ & MH447655 & MH548335 & - \\
\hline CMW 48033 & & Hawaii & A. koa (tree no. 12) & MH447660g & - & - \\
\hline CMW 48034 & Lasiodiplodia exigua $(=$ L. americana $)$ & Hawaii & A. koa (tree no. 22) & MH447661 & MH548342 & MH548333 \\
\hline CMW 46452 & L. iraniensis $(=$ L. jatrophicola $)$ & La Réunion & A. heterophylla (tree no. 12) & MH447645 & MH548344 & MH548322 \\
\hline CMW 46453 & & La Réunion & A. heterophylla (tree no. 12) & MH447646 & - & - \\
\hline CMW 46456 & & La Réunion & A. heterophylla (tree no. 15) & MH447648 & MH548346 & MH548323 \\
\hline CMW 46459 & L. rubropurpurea & La Réunion & A. heterophylla (tree no. 2) & MH447650 & - & MH548325 \\
\hline CMW 48036 & L. theobromae & Hawaii & A. koa (tree no. 13 ) & MH447662g & MH548339 & MH548334 \\
\hline AK13 3.2a & L. theobromae & Hawaii & A. koa (tree no. 13) & MN103789 & MN119480 & MN119475 \\
\hline AK13 3.2b & L. theobromae & Hawaii & A. koa (tree no. 13) & MN103790 & - & MN119476 \\
\hline CMW 48021 & Neofusicoccum occulatum & Hawaii & A. koa (tree no. 28) & MH447656 & MH548343 & MH548330 \\
\hline CMW 48023 & N. occulatum & Hawaii & A. koa (tree no. 20) & MH447658 & MH548340 & MH548332 \\
\hline CMW 48024 & N. occulatum & Hawaii & A. koa (tree no. 28 ) & MH447659 & - & - \\
\hline AK24 2.4 & N. occulatum & Hawaii & A. koa (tree no. 24) & MN103793 & MN119483 & MN119479 \\
\hline CMW 48022 & N. parvum & Hawaii & A. koa (tree no. 20) & MH447657 & MH548341 & MH548331 \\
\hline CMW 46455 & N. parvum & La Réunion & A. heterophylla (tree no. 10) & MH447647 & MH548345 & - \\
\hline AK20 3.6a & N. parvum & Hawaii & A. koa (tree no. 20$)$ & MN103791 & MN119481 & MN119477 \\
\hline AK20 3.6c & N. parvum & Hawaii & A. koa (tree no. 20) & MN103792 & MN119482 & MN119478 \\
\hline
\end{tabular}

Islands and four species from A. heterophylla from La Réunion (Fig. 2). N. parvum was the only species shared between La Réunion and the Hawaiian Islands (Fig. 3).

\subsection{Morphological characteristics}

The isolates in the clades corresponding to new species of Dothiorella had pale to dark olivaceous colonies with short aerial hyphae. The cultures produced rosette-like growth patterns and had dense mycelium with irregular edges.

\subsection{Taxonomy}

Three unidentified species emerging from the phylogenetic analyses are described as follows:

Dothiorella reunionis Marinc., Jami \& M.J. Wingf., sp. nov. (Fig. 4). MycoBank No.: MB 825260.

Etymology: Name refers to La Réunion island where this species was collected.

Conidiomata formed on hardwood twigs placed in $2 \%$ MEA at $25{ }^{\circ} \mathrm{C}$ under near-UV light for 2 weeks, stromatic, uni- or multiloculate, immersed, erumpent, superficial, covered abundantly with pigmented hyphae, 220-455 $\mu \mathrm{m}$ tall, 205-660 $\mu \mathrm{m}$ wide. Conidiophores hyaline, generally unbranched, septate, often reduced to conidiogenous cells. Conidiogenous cells discrete, hyaline or slightly pigmented, clavate to cylindrical, some with annellations, 4-14 $\mu \mathrm{m}$ long, 2-6.5 $\mu \mathrm{m}$ wide. Conidia hyaline when young, becoming brown with age, verruculous (noticeable in higher magnification, $\times 100$ ), ellipsoidal with truncate base, tapering towards the base, 1(-3)-septate, septum median, supra- or submedian, $18.5-31.5 \times 8.5-13.5 \mu \mathrm{m}$ (avg. $24.9 \times 10.6 \mu \mathrm{m}$ ). Spermatiaproducing cells hyaline, clavate to cylindrical, straight to curved, 7-15.5 $\mu \mathrm{m}$ long, 2-7 $\mu \mathrm{m}$ wide. Spermatia hyaline, shape variable, ellipsoidal to cylindrical and intermediate forms, mostly aseptate, with base truncate, straight or curved, 6-15.5 $\times 2.5-5.5 \mu \mathrm{m}$ (avg. $9.7 \times 4.0 \mu \mathrm{m})$.
Culture characteristics on $2 \%$ MEA in the dark showing optimum growth at $25{ }^{\circ} \mathrm{C}$ reaching $75.5 \mathrm{~mm}$ diam in $4 \mathrm{~d}$, followed by at $20^{\circ} \mathrm{C}$ reaching $70.2 \mathrm{~mm}$, no growth at $35{ }^{\circ} \mathrm{C}$, showing circular growth with even margin, aerial mycelium not dense, becoming abundant and fluffy at lower temperatures, culture texture and colour varying at different temperatures, at $25{ }^{\circ} \mathrm{C}$ in $4 \mathrm{~d}$ culture covered with white aerial hyphae with a tint of pale greenish brown in an inner circle.

Specimen examined: La Réunion, asymptomatic branch of Acacia heterophylla, Mar. 2015, M.J. Wingfield, PREM 62202, holotype, culture ex-holotype CMW 46457 = PPRI 25142.

Note: Although only a single isolate was obtained for this species, we have described it as new taxon, because it forms in a distinct lineage among other Dothiorella species. D. reunionis differs with Do. sarmentorum (Fr.) A.J.L. Phillips et al., by 1 bp in ITS and 7 bp in TEF-1 $\alpha$.

Dothiorella heterophyllae Marinc., Jami \& M.J. Wingf., sp. nov. (Fig. 5.). MycoBank No.: MB 825261.

Etymology: Name refers to the host species from which it was isolated, Acacia heterophylla.

Conidiomata formed on hardwood twig placed in $2 \%$ MEA at $25{ }^{\circ} \mathrm{C}$ under near-UV light for 2 weeks, stromatic, immersed, erumpent, covered with numerous pigmented hyphae, 225-345 $\mu \mathrm{m}$ tall, $210-440 \mu \mathrm{m}$ wide. Conidiophores lining inside the conidiomatal wall, mostly reduced to conidiogenous cells. Conidiogenous cells discrete, blastic, hyaline, cylindrical to clavate, with annellations, 7-16.5 $\mu \mathrm{m}$ long, $2.5-6 \mu \mathrm{m}$ wide. Conidia hyaline when young, becoming brown when mature, verruculous, ellipsoidal, tapering towards a truncated base, 1-septate, septum median, $18-26 \times 8.5-11.5 \mu \mathrm{m}$ (av. $22.6 \times 9.8 \mu \mathrm{m}$ ).

Culture characteristics on $2 \%$ MEA in the dark showing optimum growth at $20{ }^{\circ} \mathrm{C}$ reaching $80.5 \mathrm{~mm}$ in $7 \mathrm{~d}$, followed by at $15{ }^{\circ} \mathrm{C}$ reaching $69.3 \mathrm{~mm}$, no growth at $30^{\circ} \mathrm{C}$ and $35^{\circ} \mathrm{C}$, showing circular growth with undulate margin, aerial mycelium sparse, olivaceous brown, culture texture and colour relatively uniform at different temperatures, at $10{ }^{\circ} \mathrm{C}$ and $25{ }^{\circ} \mathrm{C}$ more aerial hyphae present and less pigmentation. 

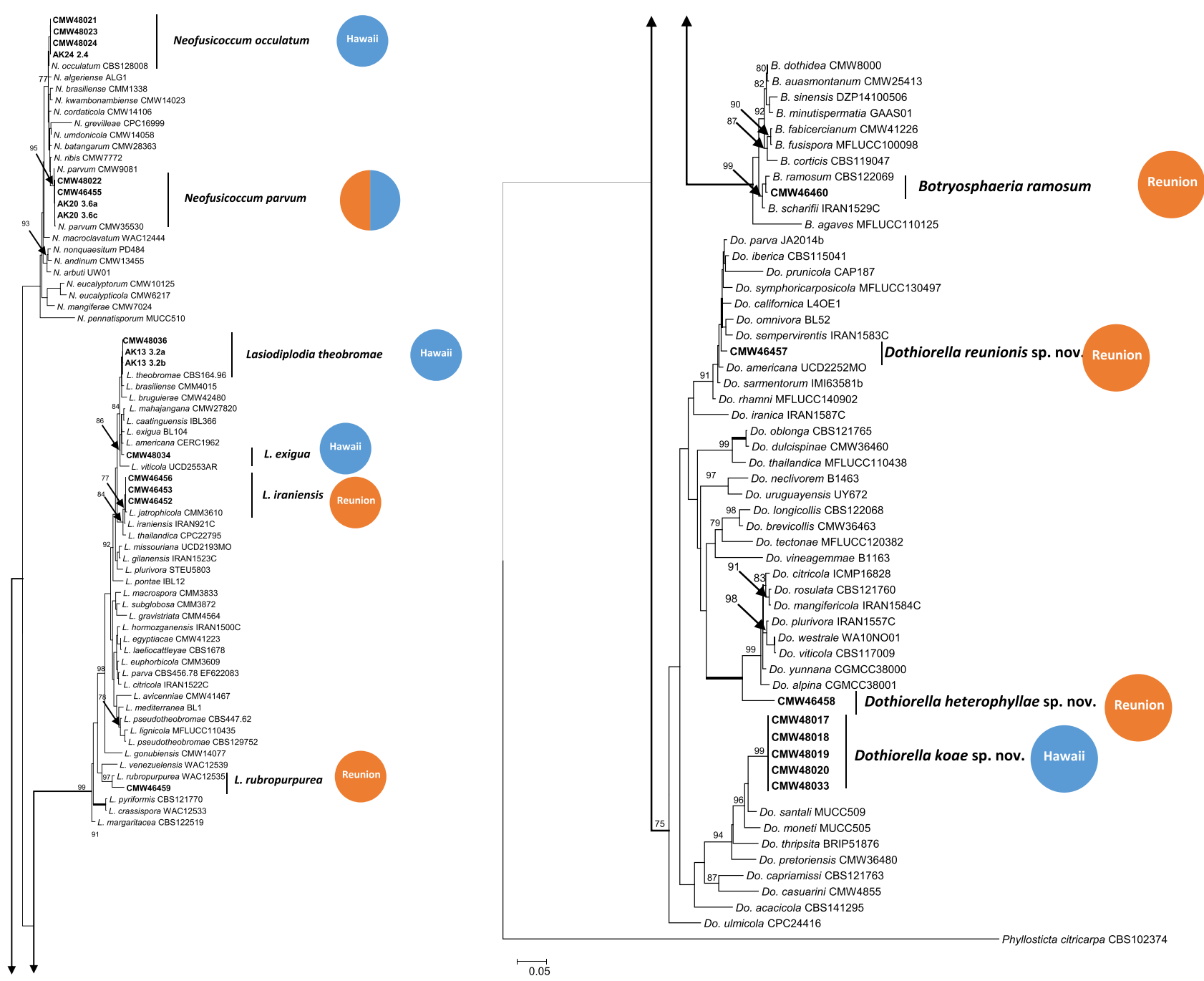

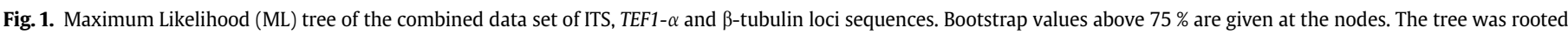
to Phyllosticta citricarpa (CBS 102374). Isolates of this study are indicated as bold.

S. examined: La Réunion, asymptomatic branch of Acacia heterophylla, Mar. 2015, M.J. Wingfield, PREM 62203, holotype, culture ex-holotype CMW 46458 = PPRI 25141.

Note: Although only a single isolate was obtained for this species we have described it as new taxon, because it forms as a distinct lineage based on ITS, TUB2 and TEF- $1 \alpha$ sequences among other Dothiorella species.

Dothiorella koae Marinc., Jami \& M.J. Wingf., sp. nov. (Fig. 6). MycoBank No.: MB 825262.

Etymology: Name refers to the host species from which it was isolated, A. koa.

Conidiomata formed on hardwood twig placed in $2 \%$ MEA at $25{ }^{\circ} \mathrm{C}$ under near-UV light for 2 weeks, stromatic, uni- or multiloculate, immersed, erumpent or superficial, moderately covered with pigmented hyphae, $120-480 \mu \mathrm{m}$ tall, $165-470 \mu \mathrm{m}$ wide. Conidiophores lining inside the wall, often reduced to conidiogenous cells. Conidiogenous cells discrete, determinate, blastic, hyaline, cylindrical to clavate, $6-11 \mu \mathrm{m}$ long, $2-4.5 \mu \mathrm{m}$ wide. Conidia hyaline when young, becoming brown with maturity, smooth becoming verruculose, fusiform to cylindrical with a round apex and a truncated base, sometimes abruptly tapering towards the base, mostly straight, 1-2-septate, septum median, supra- or submedian, septa not evenly distributed when more than one, 24.5-35 × 6.5-9.5 $\mu \mathrm{m}$ (avg. $29.5 \times 8.1 \mu \mathrm{m})$.

Culture characteristics on $2 \%$ MEA in the dark showing optimum growth at $25{ }^{\circ} \mathrm{C}$ reaching $74.5 \mathrm{~mm}$ in $7 \mathrm{~d}$, followed by at $20^{\circ} \mathrm{C}$ reaching $54.5 \mathrm{~mm}$, no growth at $30^{\circ} \mathrm{C}$ and $35^{\circ} \mathrm{C}$, showing circular growth with undulate margin, aerial mycelium moderately dense, at $20{ }^{\circ} \mathrm{C}$ creamy aerial mycelium densely packed near the centre, culture morphology similar at different temperature, tint of greenish brown in culture.

Specimens examined: Hawaii, asymptomatic branches of Acacia koa, Apr 2015, M.J. Wingfield, PREM 62204, holotype, culture exholotype CMW 48017 = PPRI 25139; additional cultures CMW 48018 = PPRI 25140, CMW 48019, CMW 48020, CMW 48033.

Notes: This species not only formed a distinct phylogenetic clade among Dothiorella species and differs with Dothiorella santali K.M. Taylor et al., based on unique fixed alleles in ITS (3 bp), TUB2 (5 bp) and TEF-1 $\alpha$ (12 bp) sequences data, but also had very distinct conidia. The conidia are distinguishable from other species of Dothiorella by being narrow and being predominantly 2 septate. 


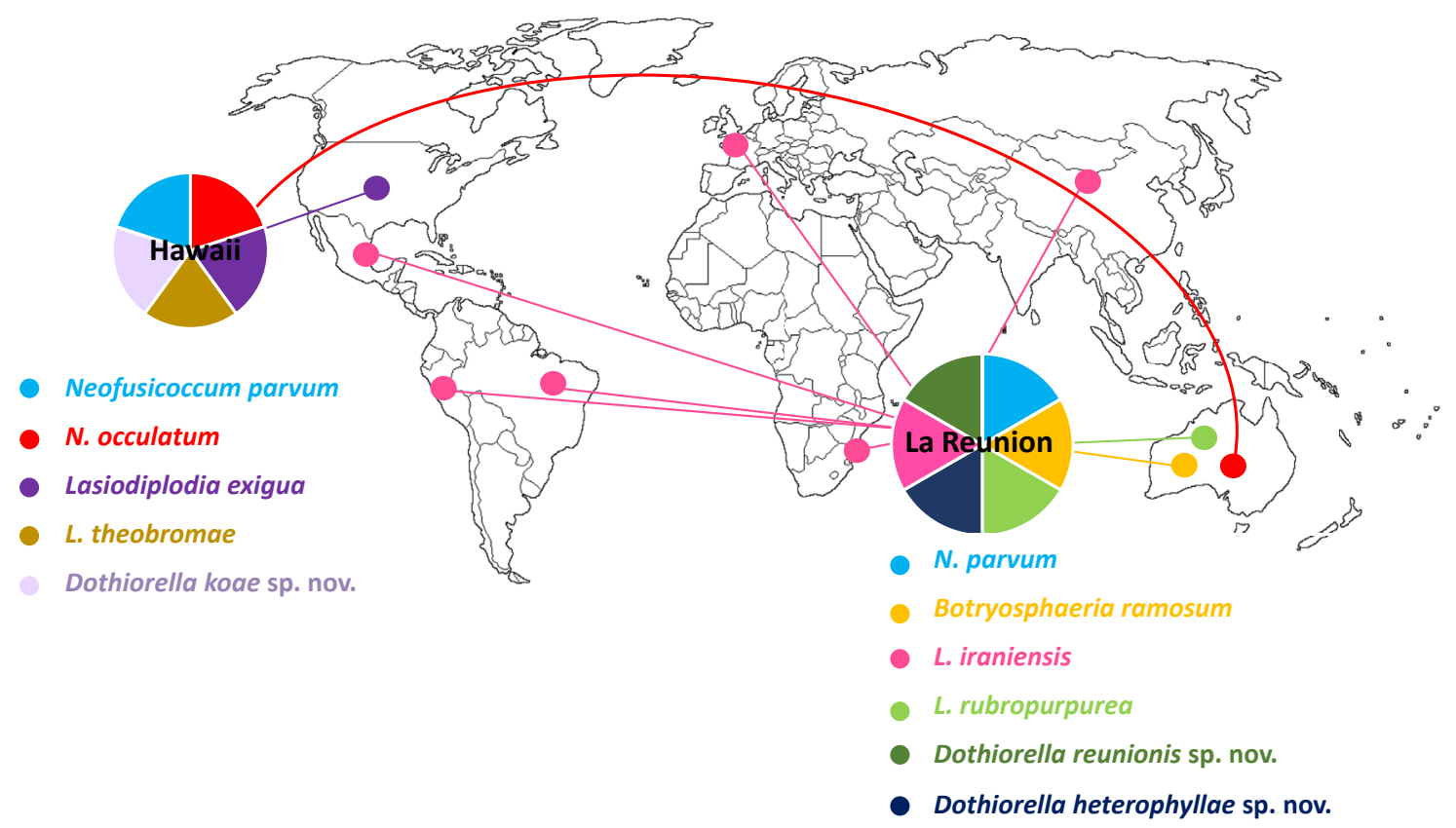

Fig. 2. The distribution of ten Botryosphaeriaceae species of this study in Hawaii and La Réunion Islands and across the world. *These two species exist all over the world.

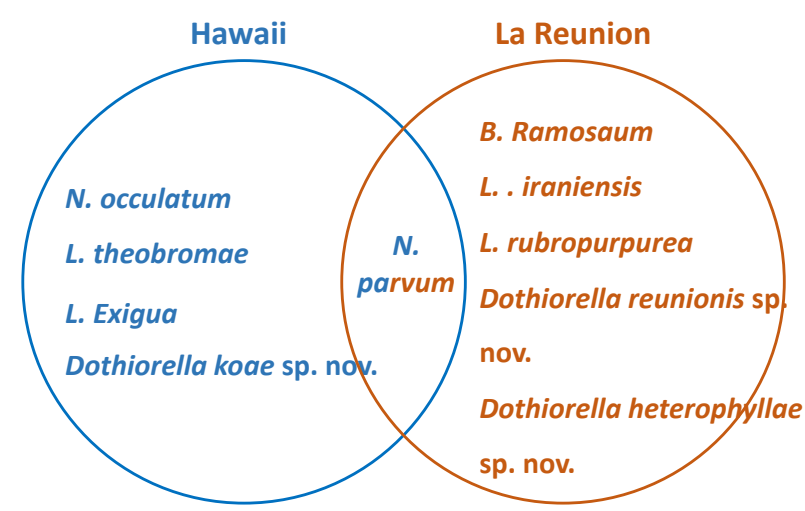

Fig. 3. The pattern of overlapping Botryosphaeriaceae species between Hawaii and La Réunion Islands.

\section{Discussion}

Ten Botryosphaeriaceae species were identified from branches of asymptomatic $A$. koa and $A$. heterophylla in Hawaiian Islands and La Réunion, respectively. With only one exception, these Botryosphaeriaceae were unique to the islands from which they were sampled. Four unique species were identified from $A$. koa and five species from A. heterophylla. Only N. parvum occurred in association with trees from both regions. Three other known species, $N$. occulatum, $L$. exigua (=L. americana), $L$. theobromae, and a new Dothiorella species were identified on A. koa. Similarly, three known species including $L$. iraniensis (=L. jatrophicola), L. rubropurpurea and $B$. ramosum, and two new Dothiorella species were identified in association with $A$. heterophylla. Overall, our results expand the geographical and host range of Botryosphaeriaceae and provide the first Botryosphaeriaceae records for both the locations and hosts studied.

All three new species of this study resided in the genus Dothiorella. They include Do. reunionis and Do. heterophyllae described on A. heterophylla in La Réunion and Do. koae on A. koa in
Hawaiian Islands. Another Dothiorella sp., Do. acacicola Crous \& M.J. Wingf. has been described from La Réunion where it was isolated from leaves of Acacia mearnsii De Wild. (Crous et al., 2016b). Acacia mearnsii is the most widespread invasive woody plant in La Réunion, which is very competitive with $A$. heterophylla and has negatively impacted on the regeneration of $A$. heterophylla (Tassin, 2002). Dothiorella acacicola was not found on A. heterophylla in this study even though these trees grow in close proximity to each other. This could reflect host specificity in the fungus or an artefact of sampling.

It was not surprising that $N$. parvum was found on both $A$. koa in Hawaii and $A$. heterophylla, despite their geographic separation. $N$. parvum has a wide global distribution and host range (Slippers and Wingfield, 2007) and has been reported from 29 countries on 90 hosts (Sakalidis et al., 2013). In South Africa N. parvum has been reported from 30 hosts across 12 locations, making it the second most widespread species of the Botryosphaeriales with the highest host diversity in that country (Jami et al., 2017). All evidence suggests that this species has been moved widely through the global trade in plants and plant products. It is likely that its wide host range, and evident adaptability to a wide climatic range, contributes to its ability to establish and spread in new areas after introduction.

An interesting result of this study was that $L$. theobromae was found only on A. koa in Hawaii. This was contrary to the fact that this is one of the most widespread Botryosphaeriaceae species globally, having been reported on large number of hosts (https://nt. ars-grin.r gov/fungaldatabases) and on all continents except Antarctica (Mehl et al., 2017). The species tends to occur on trees in warmer parts of the world and its occurrence in Hawaiian Islands might reflect this fact. Although, La Réunion is a tropical region too, however, the absent of $L$. theobromae from there is likely a sampling effect.

Three species, B. ramosum, L. iraniensis and L. rubropurpurea, were found only on $A$. heterophylla in La Réunion. These species are known on various other woody plants such as Eucalyptus in Australia in the case of B. ramosum and L. rubropurpurea (Burgess et al., 2006; Pavlic et al., 2008) and a wide diversity of woody 

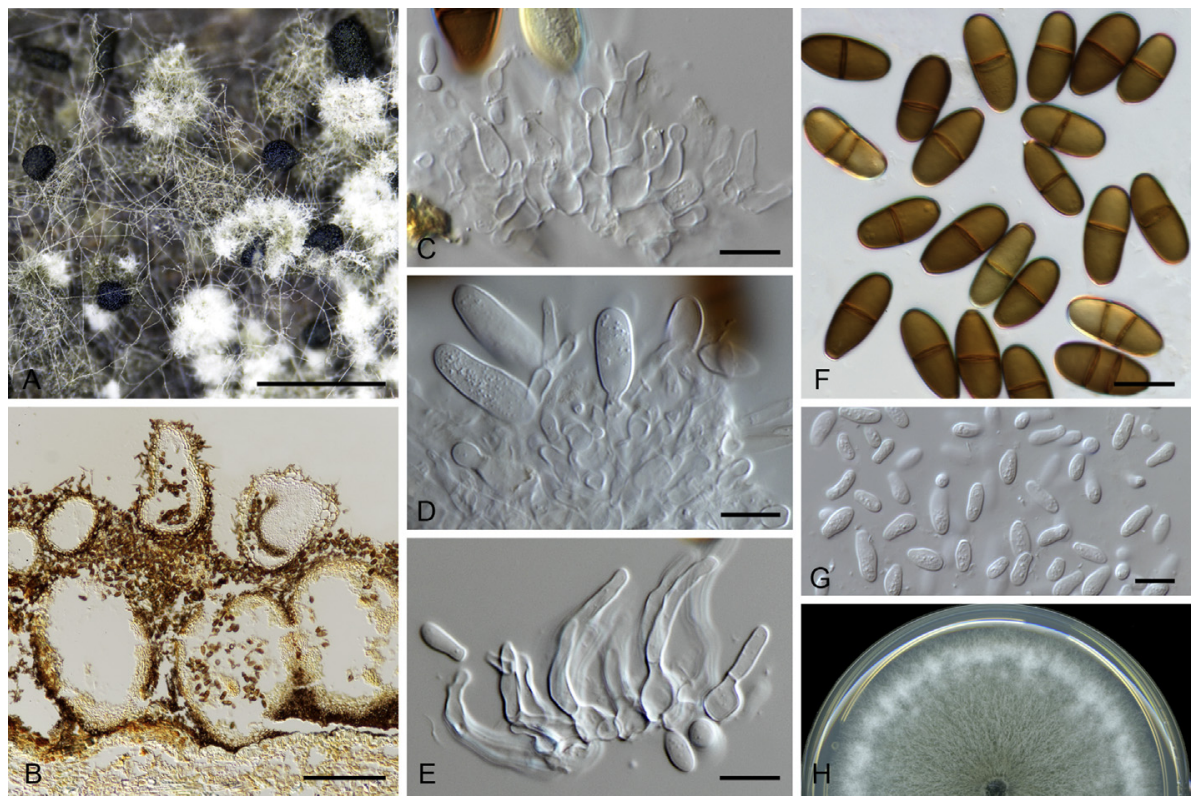

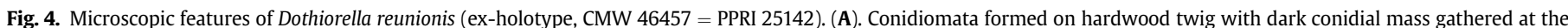

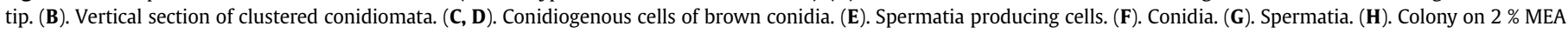
showing optimum growth in the dark at $25^{\circ} \mathrm{C}$ in $4 \mathrm{~d}$. Scale bars: $\mathrm{A}=1 \mathrm{~mm} ; \mathrm{B}=250 \mu \mathrm{m} ; \mathrm{C}-\mathrm{G}=10 \mu \mathrm{m}$.
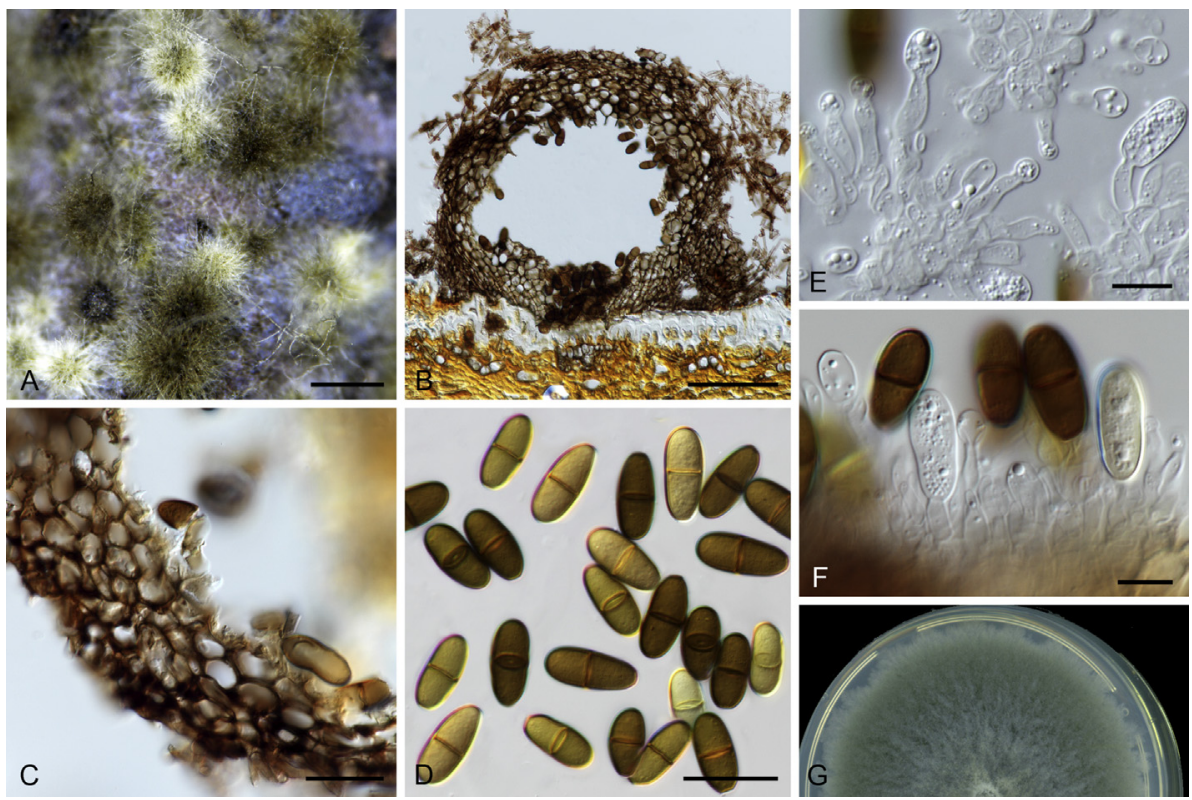

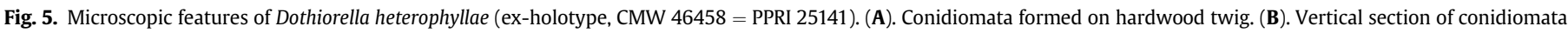

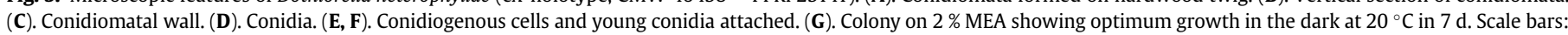
$\mathrm{A}=500 \mu \mathrm{m} ; \mathrm{B}=100 \mu \mathrm{m} ; \mathrm{C}, \mathrm{D}=25 \mu \mathrm{m} ; \mathrm{E}, \mathrm{F}=10 \mu \mathrm{m}$.

plants in many different parts of the world for L. iraniensis (Abdollahzadeh et al., 2010; Correia et al., 2016; Cruywagen et al., 2017; Machado et al., 2014; Netto et al., 2017; Rodríguez-Gálvez et al., 2017; Sakalidis et al., 2011b; Yang et al., 2017; Zhu et al., 2015). This species could have been accidently co-introduced into La Réunion with other woody plants.

Lasiodiplodia exigua and $N$. occulatum were isolated only from A. koa (Hawaiian Islands). Lasiodiplodia exigua has been reported on Pistacia vera $\mathrm{L}$. and Retama raetam (Forssk.) Webb in USA and Tunisia, respectively, as well as from Adansonia sp. L. in Cameroon and Senegal (Chen et al., 2015; Cruywagen et al., 2017; Linaldeddu et al., 2015). Neofusicoccum occulatum has been reported from Wollemia nobilis W.G.Jones et al., and Eucalyptus L'Hérit. species in Australia (Sakalidis et al., 2011c), as well as from non-native Psidium guajava L. in Hawaii (Yang et al., 2017). Our results represent a new host association for both $L$. exigua and $N$. occulatum but their wide distribution elsewhere in the world suggests that they have probably been introduced into the Hawaiian Islands.

The origin of the Botryosphaeriaceae on A. koa in Hawaiian Islands and $A$. heterophylla in La Réunion is unknown. The Botryosphaeriaceae are clearly promiscuous and they are not known to be transferred vertically i.e. internally with seed (Bihon et al., 2011). 

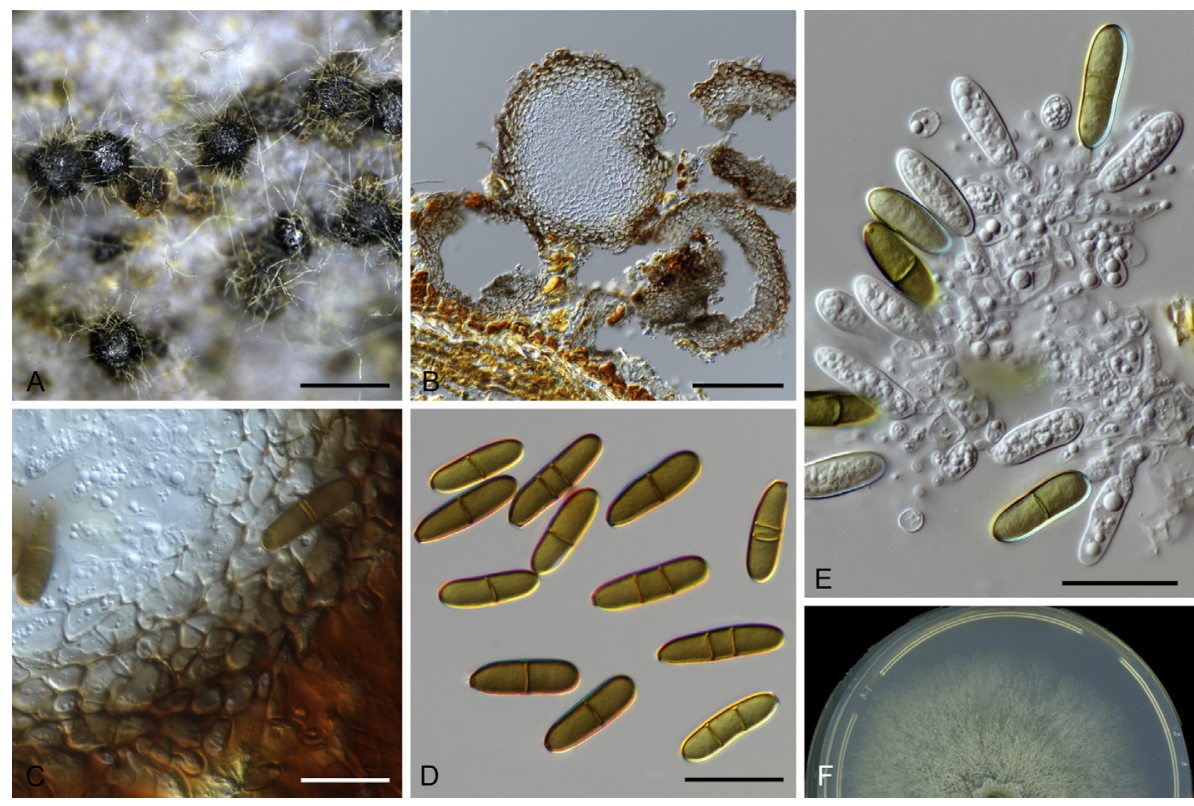

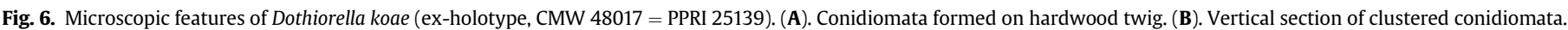

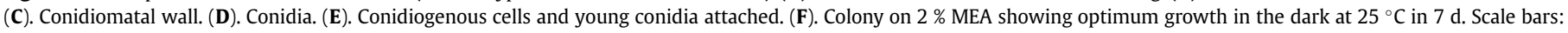
$\mathrm{A}=500 \mu \mathrm{m} ; \mathrm{B}=100 \mu \mathrm{m} ; \mathrm{C}-\mathrm{E}=25 \mu \mathrm{m}$.

Consequently, if seed provided the first source of $A$. heterophylla in La Réunion, the Botryosphaeriaceae are unlikely to have been transferred at the same time. Most of the species detected in this study have been found elsewhere in the world and anthropogenic movement of plant material could have brought most of them to these islands. Some of the species could be native to their respective hosts or islands but sampling of a wide range of native trees in these areas would be needed to support this notion. Overall, the results of this study show that two closely related trees, A. koa and A. heterophylla, have been colonised by numerous, most likely invasive, Botryosphaeriaceae in the two areas where these trees occur naturally, without any associations relating to the origin of these trees.

\section{Acknowledgments}

We thank Dr Trudy Paap for reviewing a draft version of the manuscript. Members of the Tree Protection Cooperative Programme (TPCP), the DST/NRF Centre of Excellence for Invasion Biology, Centre of Excellence in Tree Health Biotechnology (CTHB) and the University of Pretoria, South Africa, are acknowledged for financial support.

\section{Appendix A. Supplementary data}

Supplementary data to this article can be found online at https://doi.org/10.1016/j.funbio.2019.07.001.

\section{References}

Abdollahzadeh, J., Javadi, A., Goltapeh, E.M., Zare, R., Phillips, A.J.L., 2010. Phylogeny and morphology of four new species of Lasiodiplodia from Iran. Persoonia 25, $1-10$.

Bihon, W., Slippers, B., Burgess, T.I., Wingfield, M.J., Wingfield, B.D., 2011. Sources of Diplodia pinea endophytic infections in Pinus patula and $P$. radiata seedlings in South Africa. For. Pathol. 41, 370-375.

Brown, G.K., Murphy, D.J., Kidman, J., Ladiges, P.Y., 2012. Phylogenetic connections of Phyllodinous species of Acacia outside Australia are explained by geological history and human-mediated dispersal. Aust. Syst. Bot. 25, 390-403.

Burgess, T.I., Wingfield, M.J., 2017. Pathogens on the move: a 100-year global experiment with planted eucalypts. Bioscience 67, 14-25.
Burgess, T.I., Barber, P.A., Mohali, S., Pegg, G., de Beer, W., Wingfield, M.J., 2006. Three new Lasiodiplodia spp. from the tropics, recognized based on DNA sequence comparisons and morphology. Mycologia 98, 423-435.

Carbone, I., Kohn, L.M., 1999. A method for designing primer sets for speciation studies in filamentous Ascomycetes. Mycologia 91, 553-556.

Chen, S., Li, G., Liu, F., Michailides, T.J., 2015. Novel species of Botryosphaeriaceae associated with shoot blight of pistachio. Mycologia 107, 780-792.

Correia, K., Silva, M., Morais, M., Armengol, J., Phillips, A., Câmara, M., Michereff, S. 2016. Phylogeny, distribution and pathogenicity of Lasiodiplodia species associated with dieback of table grape in the main Brazilian exporting region. Plant Pathol. 65, 92-103.

Crous, P.W., Groenewald, J.Z., Slippers, B., Wingfield, M.J., 2016a. Global food and fibre security threatened by current inefficiencies in fungal identification. Philos. Trans. R. Soc. B 371, 20160024.

Crous, P.W., Wingfield, M.J., Richardson, D.M., Le Roux, J.J., Strasberg, D., Edwards, J., Roets, F., Hubka, V., Taylor, P., Heykoop, M., 2016b. Fungal Planet description sheets, 400-468. Persoonia 36, 316-458.

Crous, P.W., Groenewald, J.Z., Risède, J.-M., Simoneau, P., Hywel-Jones, N.L., 2004. Calonectria species and their Cylindrocladium anamorphs: species with sphaeropedunculate vesicles. Stud. Mycol. 50, 415-430.

Crous, P.W., Wingfield, M.J., Burgess, T., Hardy, G.E.S.J., Crane, C., Barrett, S., CanoLira, J., Le Roux, J., Thangavel, R., Guarro, J., 2017. Fungal Planet description sheets, 469-557. Persoonia 37, 218.

Cruywagen, E.M., Slippers, B., Roux, J., Wingfield, M.J., 2017. Phylogenetic species recognition and hybridisation in Lasiodiplodia: a case study on species from baobabs. Fungal Biol. 121, 420-436.

Desprez-Loustau, M.L., Marçais, B., Nageleisen, L.M., Piou, D., Vannini, A., 2006. Interactive effects of drought and pathogens in forest trees. Ann. For. Sci. 63, 597-612.

Gardes, M., Bruns, T.D., 1993. ITS primers with enhanced specificity for basidiomycetes application to the identification of mycorrhizae and rusts. Mol. Ecol. 2, $113-118$.

Glass, N.L., Donaldson, G.C., 1995. Development of primer sets designed for use with the PCR to amplify conserved genes from filamentous ascomycetes. Appl. Environ. Microbiol. 61, 1323-1330.

Hernandez-Restrepo, M., Schumacher, R.K., Wingfield, M.J., Ishtiaq, A., Cai, L., Duong, T.A., Edwards, J., Gene, J., Groenewald, J.Z., Sana, J., 2016. Fungal systematics and evolution: FUSE 2. Sydowia 68, 193-230.

Jami, F., Slippers, B., Wingfield, M.J., Gryzenhout, M., 2012. Five new species of the Botryosphaeriaceae from Acacia karroo in South Africa. Cryptog. Mycol. 33, 245-266.

Jami, F., Wingfield, M.J., Gryzenhout, M., Slippers, B., 2017. Diversity of tree-infecting Botryosphaeriales on native and non-native trees in South Africa and Namibia. Australas. Plant Pathol. 46, 529-545.

Le Roux, J.J., Strasberg, D., Rouget, M., Morden, C.W., Koordom, M., Richardson, D.M., 2014. Relatedness defies biogeography: the tale of two island endemics (Acacia heterophylla and A. koa). New Phytol. 204, 230-242.

Linaldeddu, B., Deidda, A., Scanu, B., Franceschini, A., Serra, S., Berraf-Tebbal, A., Boutiti, M.Z., Jamâa, M.B., Phillips, A., 2015. Diversity of Botryosphaeriaceae 
species associated with grapevine and other woody hosts in Italy, Algeria and Tunisia, with descriptions of Lasiodiplodia exigua and Lasiodiplodia mediterranea sp. nov. Fungal Divers. 71, 201-214.

Marsberg, A., Kemler, M., Jami, F., Nagel, J.H., Postma-Smidt, A., Naidoo, S., Wingfield, M.J., Crous, P.W., Spatafora, J.W., Hesse, C.N., Robbertse, B., 2017. Botryosphaeria dothidea: a latent pathogen of global importance to woody plant health. Mol. Plant Pathol. 18, 477-488.

Machado, A.R., Pinho, D.B., Pereira, O.L., 2014. Phylogeny, identification and pathogenicity of the Botryosphaeriaceae associated with collar and root rot of the biofuel plant Jatropha curcas in Brazil, with a description of new species of Lasiodiplodia. Fungal Divers. 67, 231-247.

Mehl, J.W., Slippers, B., Roux, J., Wingfield, M.J., 2013. Cankers and other diseases caused by the Botryosphaeriaceae. In: Gonthier, P., Nicolotti, G. (Eds.), Infectious Forest Diseases. CAB International, Oxon, UK, pp. 298-317.

Mehl, J.W., Slippers, B., Roux, J., Wingfield, M.J., 2017. Overlap of latent pathogens in the Botryosphaeriaceae on a native and agricultural host. Fungal Biol. 121, 405-419.

Netto, M.S., Lima, W.G., Correia, K.C., Da Silva, C.F., Thon, M., Martins, R.B., Miller, R.N., Michereff, S.J., Câmara, M.P., 2017. Analysis of phylogeny, distribution, and pathogenicity of Botryosphaeriaceae species associated with gummosis of Anacardium in Brazil, with a new species of Lasiodiplodia. Fungal Biol. 121, 437-451.

Pavlic, D., Wingfield, M.J., Barber, P., Slippers, B., Hardy, G.E.S.J., Burgess, T.I., 2008. Seven new species of the Botryosphaeriaceae from baobab and other native trees in Western Australia. Mycologia 100, 851-866.

Posada, D., Buckley, T.R., 2004. Model selection and model averaging in phylogenetics: advantages of Akaike information criterion and Bayesian approaches over likelihood ratio tests. Syst. Biol. 53, 793-808.

Rayner, R.W., 1970. A Mycological Colour Chart. Commonwealth Mycological Institute and British Mycological Society, Kew, Surrey, U. K.

Rodríguez-Gálvez, E., Guerrero, P., Barradas, C., Crous, P.W., Alves, A., 2017. Phylogeny and pathogenicity of Lasiodiplodia species associated with dieback of mango in Peru. Fungal Biol. 121, 452-465.

Sakalidis, M.L., Hardy, G.E.S.J., Burgess, T.I., 2011a. Class III endophytes, clandestine movement amongst hosts and habitats and their potential for disease; a focus on Neofusicoccum australe. Australas. Plant Pathol. 40, 510-521.
Sakalidis, M.L., Ray, J.D., Lanoiselet, V., Hardy, G.E.S.J., Burgess, T.I., 2011b. Pathogenic Botryosphaeriaceae associated with Mangifera indica in the Kimberley region of Western Australia. Eur. J. Plant Pathol. 130, 379-391.

Sakalidis, M.L., Hardy, G.E.S.J., Burgess, T.I., 2011c. Use of the Genealogical Sorting Index (GSI) to delineate species boundaries in the Neofusicoccum parvum/Neofusicoccum ribis species complex. Mol. Phylogenetics Evol. 60, 333-344.

Sakalidis, M.L., Slippers, B., Wingfield, B.D., Hardy, G.E.S.J., Burgess, T.I., 2013. The challenge of understanding the origin, pathways and extent of fungal invasions: global populations of the Neofusicoccum parvum/N. ribis species complex. Divers. Distrib. 19, 873-1094.

Scholler, M., Aime, M.C., 2006. On some rust fungi (Uredinales) collected in an Acacic koa-Metrosideros polymorpha woodland, Mauna Loa Road, Big island, Hawaii. Mycoscience 47, 159-165.

Slippers, B., Crous, P.W, Jami, F., Groenewald, J.Z., Wingfield, M., 2017. Diversity in the Botryosphaeriales: looking back, looking forward. Fungal Biol. 121 307-321.

Slippers, B., Wingfield, M.J., 2007. Botryosphaeriaceae as endophytes and latent pathogens of woody plants: diversity, ecology and impact. Fungal Biol. Rev. 21, 90-106.

Sturrock, R., Frankel, S., Brown, A., Hennon, P., Kliejunas, J., Lewis, K., Worrall, J. Woods, A., 2011. Climate change and forest diseases. Plant Pathol. 60, 133-149.

Tassin, J., 2002. Dynamiques et conse'quences de l'invasion des paysages agricoles des Hauts de La Re'union par Acacia mearnsii de Wild. Université Paul Sabatier Toulouse III, France.

Van Zandt, M., Delparte, D., Hart, P., Duvall, F., Penniman, J., 2014. Nesting characteristics and habitat use of the endangered Hawaiian petrel (Pterodroma sandwichensis) on the island of Lāna'i. Waterbirds 37, 43-51.

White, T.J., Bruns, T., Lee, S., Taylor, J., 1990. Amplification and direct sequencing of fungal ribosomal RNA genes for phylogenetics. In: Innis, M.A., Gelfaud, D.H., Sninsky, J.J., White, T.J. (Eds.), PCR Protocols. A Guide to Methods and Applications. Academic Press, San Diego, CA, USA, pp. 315-322.

Yang, T., Groenewald, J.Z., Cheewangkoon, R., Jami, F., Abdollahzadeh, J., Lombard, L. Crous, P.W., 2017. Families, genera, and species of Botryosphaeriales. Fungal Biol. $121,322-346$.

Zhu, H., Qin, W.-Q., Liu, L., Yan, W., 2015. First report of leaf spot of clustering Fishtail palm (Caryota mitis) caused by Lasiodiplodia jatrophicola in China. Plant Dis. 99, 1038-1038. 